\title{
Content Analysis of the Freshwater Aquaculture Cyber Extension Materials in Indonesia
}

\author{
Ridar Hendri ${ }^{\text {a,* }}$, Haslinda Sutan Ahmad Nawi ${ }^{\text {b }}$, Azmuddin Ibrahim ${ }^{\mathrm{c}}$ \\ ${ }^{a}$ Department of Socioeconomics, Faculty of Fisheries and Marine, University of Riau, Pekanbaru, Indonesia \\ ${ }^{b}$ Department of Information Technology, Faculty of Communication, Visual Art \& Computing, Universiti Selangor, Bestari Jaya, Malaysia \\ ${ }^{c}$ Department of Communication, Faculty of Communication, Visual Art \& Computing, Universiti Selangor, Bestari Jaya, Malaysia \\ Corresponding author: ${ }^{*}$ ridar.hendri@lecturer.unri.ac.id
}

\begin{abstract}
This study aims to analyse the content of freshwater aquaculture cyber-extension materials presented on the MFCE website, which the Indonesian government controls. The research sample is all extension materials presented during 2013-2017, comprising of 183 titles of text, 29 titles of graphics, and 53 titles of video- sample selection by the census. The NVivo 12 Plus software was used to analyse the fish species, aquaculture management, extension material nature, and media element size presented on the website. The results showed that the three media (text, graphic, and video) presented all the six fish species of high economic value. The videos presented 58.49\% about the nile tilapia (Tilapia nilotica) species, while graphics and texts presented more on catfish (Clarias batrachus), almost $60 \%$ on average. These media also presented all the seven aquaculture management elements. Graphics and texts presents more about pond preparation, while the videos presents more about fish feed management. The texts and graphics extension media size are quate ideal. Most of the text material are 700-1,700 words, and the graphic measures 380x285 pixels (two-thirds of the gadget screen). At the same time, the video duration is ideal (4.5 - 9 minutes), there are very few, only $33.96 \%$. Most of the extension materials are in the form of recommendations, and not problem-solving. This research can there are a guide in designing a ideal content of aquaculture fisheries extension materials in Indonesia.
\end{abstract}

Keywords - Content analysis; cyber extension; freshwater aquaculture; MFCE website.

Manuscript received 20 Nov. 2020; revised 1 Mar. 2021; accepted 12 Jun. 2021. Date of publication 31 Oct. 2021. IJASEIT is licensed under a Creative Commons Attribution-Share Alike 4.0 International License.

\section{INTRODUCTION}

Freshwater aquaculture is an important sector to support the Indonesian economy. The fish production is 3,02 million tons per year with a value of USD 4,15 billion [1]. This sector is growing because Indonesia has a fertile and wide land area, 1.9 million $\mathrm{km} 2$ [2].

Aquaculture is a fish farming business at a certain location and time which applies business management principles [3], [4]. This activity is also defined as 'farming in the water', which raises animals (such as fish, shrimp, and shellfish), and plants (seaweeds). Fish farming business needs human intervention to help increase production, including finding fish-seeds, maintaining, providing food, and protecting fish from pests and diseases [5].

About four million Indonesian fish farmers are in this business. They raise fish in the ponds, floating net cages, rivers, lakes, and reservoirs [6], [7].
The Indonesian government fosters fish farmers through extension programs to increase fish production. Extension is non-formal education to increase the knowledge, attitudes, skills, and behaviour of fish farmers, so that they can solve their business problems [8], [9].

The Ministry of Marine Affairs and Fisheries (KKP) coordinates the national fisheries extension program in Indonesia. Before 2007, the ministry used conventional extension system, but now uses the cyber extension system following the development of information technology. To make it happen, KKP built the Marine and Fisheries Cyber Extension (MFCE) website.

The website contains various fishery extension materials to increase the knowledge and skill of extension workers and fish farmers in Indonesia [10]. However, in Riau Province only 20 percent fish farmers used the MFCE website [5]. They only used if the website content is useful for them. This make it is necessary to analyse the content of the extension material on the MFCE website. 


\section{MATERIALS AND MethoD}

This research was conducted in June-August 2020, using mixed methods (qualitative and quantitative). Qualitative research emphasizes the in-depth understanding of a problem; it includes collecting and analysing data in text, images, audio, and video, which aims to understand concepts, opinions, and experiences. Quantitative research is an effort to investigate problems by collecting data, determining variables, and then measuring them with numbers so that applicable statistical procedures can carry out an analysis. The purpose of quantitative research is to help draw conclusions or generalize theory predictions correctly [11].

Primary data collected were aquaculture extension materials published on the MFCE website during 2013-2017, which consisted of data in text format (183 titles), graphic format (29 titles), and video format (53 titles). The census methods was used for data collection [11]. The data analysed were fish species, aquaculture management elements, extension material nature, and media element's size.

For data analysis was used quantitative and qualitative content analysis methods, with the help of NVivo 12 Plus software [12]. Quantitative content analysis was used to measure the fish species, aquaculture management type, and media element's size. Seven categories of fish species are measured, comprising carp (Cyprinus carpio L.), giant gourami (Osphyronemus gourami), parotfish (Pangasius sutchi), catfish (Clarias batrachus), nile tilapia (Tilapia nilotica L.), tilapia fish (Tilapia mossambica) [13], [14], and "other fish". There are also seven categories of aquaculture management, consisting of pond preparation, water supply, fish seed handling, water quality management, fish feed management, fish pest \& disease control, and fish harvesting $\&$ marketing activities [15], [16].

The size of text format extension materials is divided into three categories, including shorter text (less than 700 words), medium text (700 - 1,700 words), and longer text (more than 1,700 words). Graphic format extension materials consist of three categories, thet is small size $(380 \times 214$ pixels/one-third of a gadget screen), medium size ( $380 \times 285$ pixels/two-thirds of the gadget screen width), and large size (1204 x 903 pixels) or wide as the gadget screen. Video format extension materials consist of three categories, including short duration (less than 4.5 seconds), medium duration (4.5 - 9 seconds), and longer duration (more than nine seconds) [17]. Meanwhile, the qualitative content analysis was used to measure the extension material nature, which consists of two categories, that is problem solving and recommendation [18].

\section{RESULT AND DISCUSSION}

\section{A. Text Format of Aquaculture Cyber Extension Materials}

The analysis results of the text format extension materials showed that the ikan (fish) word size in the word cloud visualization look is bigger than the other word size (except the conjunctions), as shown in Fig.1.

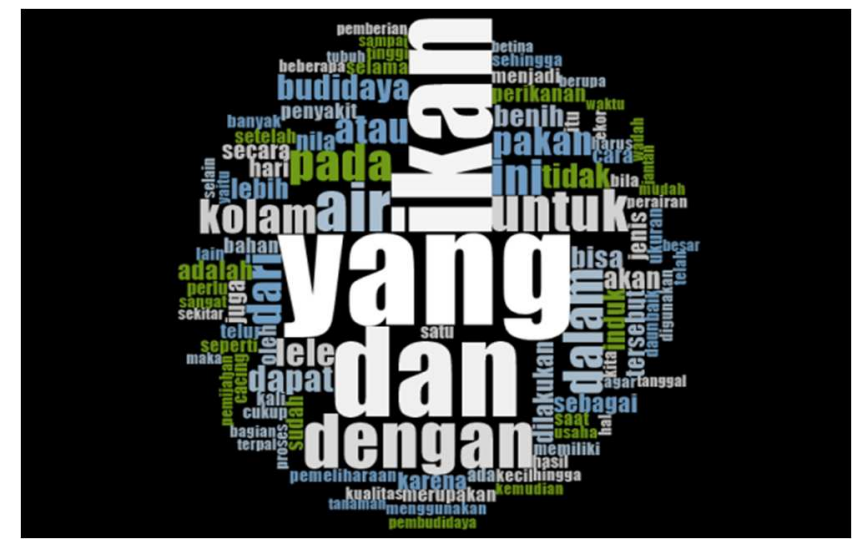

Fig. 1 The word cloud visualization for text format extension materials

This means that fish is the word that appears most often in the materials. The word "ikan" occurs 3,193 times $(2.56 \%$ of the 100 most occurring words). The ten common words that appear are fish, water, pond, feed, catfish, aquaculture, seed, mother, nile, and species, as shown in Fig 2.

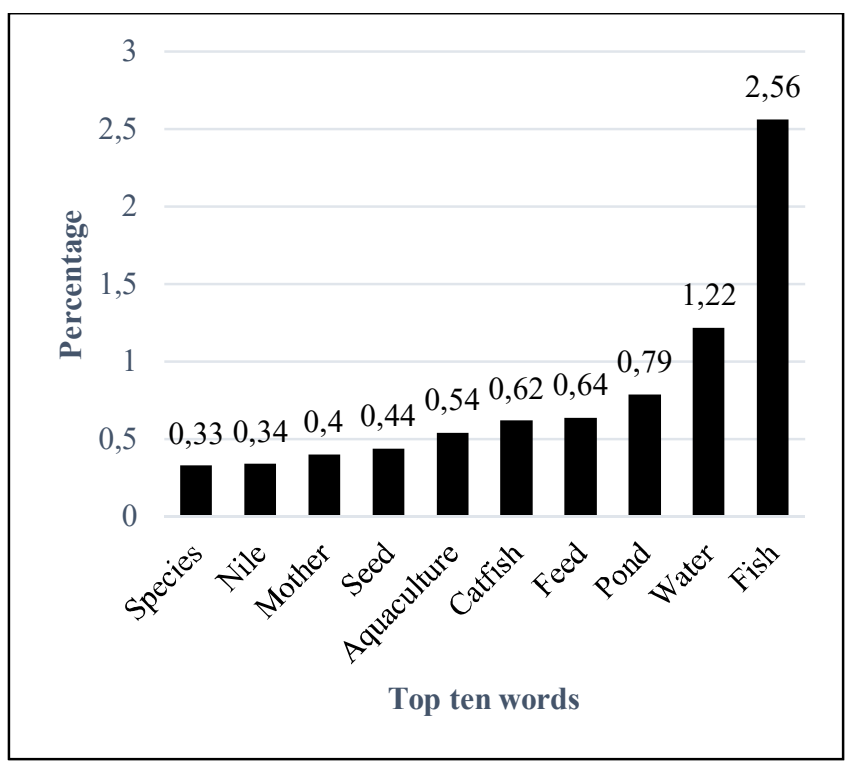

Fig. 2 Top ten words in the text format extension materials

The analysis results show that the six fish species of high economic value are discussed in the text format extension materials published on the MFCE website. Catfish is the fish species most served, 99 out of 183 materials titles $(55.10 \%)$, as shown in Table I. While tilapia fish the least (28.42\%). But, the discussion about nile tilapia, giant gourami, carp, and parrotfish is quite a lot, an average of more than $32 \%$. The "other fish" categories also appeared in quite a large number, 96 titles $(52 \%)$. However, it is not significant because this category consists of 12 fish species, so the average number is small (4.4\%). Those fish are wallago attu (Wallago leeri), arowana (Scleropages formosus), hoven's carp (Leptobarbus hoeveni), climbing perch (Anabas testudineus), kissing gourami (Helostoma themminckii), betta fish (Betta splendens), green catfish (Hemibagrus nemurus), swamp eel (Monopterus albus), eel (Anguilla marmorata), featherback (Chitala bornensis), silver barb (Barbonymus gonionotus), and koi (Cyprinus rubrofuscus). 
TABLE I

VARIABLE ANALYSIS RESULTS OF TEXT FORMAT EXTENSION MATERIALS

\begin{tabular}{|c|c|c|c|}
\hline Variables & Categories & $\begin{array}{l}\text { Number } \\
\text { of Titles }\end{array}$ & $\begin{array}{l}\text { Proportions } \\
\text { of } 183 \text { Titles } \\
(\%)\end{array}$ \\
\hline \multirow{7}{*}{$\begin{array}{l}\text { Fish } \\
\text { Species }\end{array}$} & - Catfish & 99 & 55.10 \\
\hline & - Other fish & 96 & 52.46 \\
\hline & - Nile Tilapia & 70 & 38.25 \\
\hline & - Giant Gourami & 65 & 35.52 \\
\hline & - Carp & 64 & 34.97 \\
\hline & - Parrotfish & 60 & 32.79 \\
\hline & - Tilapia Fish & 52 & 28.42 \\
\hline \multirow{7}{*}{$\begin{array}{l}\text { Elements } \\
\text { of Aqua- } \\
\text { culture } \\
\text { Manage- } \\
\text { ment }\end{array}$} & - Pond Preparation & 34 & 18.58 \\
\hline & - Fish Seed Handling & 33 & 18.03 \\
\hline & $\begin{array}{l}\text { - Water Quality } \\
\text { Management }\end{array}$ & 28 & 15.30 \\
\hline & - Feed Management & 26 & 14.21 \\
\hline & $\begin{array}{l}\text { - Fish Harvesting \& } \\
\text { Marketing Activities }\end{array}$ & 17 & 9.29 \\
\hline & - Water Supply & 16 & 8.74 \\
\hline & $\begin{array}{l}\text { - Fish Pests \& Disease } \\
\text { Control }\end{array}$ & 10 & 5.46 \\
\hline \multirow{3}{*}{$\begin{array}{l}\text { Media } \\
\text { Element } \\
\text { Size }\end{array}$} & $\begin{array}{l}\text { - Short Text (less than } \\
700 \text { words) }\end{array}$ & 54 & 29.51 \\
\hline & $\begin{array}{l}\text { - Medium Text ( } 700 \text { - } \\
\text { 1,700 words) }\end{array}$ & 122 & 66.67 \\
\hline & $\begin{array}{l}\text { - Long Text (more than } \\
\text { 1,700 words) }\end{array}$ & 7 & 3.83 \\
\hline Nature of & - Problem-solving & 89 & 48.63 \\
\hline $\begin{array}{l}\text { Extension } \\
\text { Materials }\end{array}$ & - Recommendation & 131 & 71.58 \\
\hline
\end{tabular}

So, text format extension materials, presented all species of fish, have high economic value. There are six species of freshwater fish with high economic value developed in Indonesia, including carp, giant gourami, parrotfish, catfish, nile tilapia, and tilapia fish. According to [19], the effectiveness of agricultural extension (including fisheries) will be easily achieved if the material is following the needs of the audience.

All aquaculture management categories are presented in the text format extension materials. Four of the seven categories (fish feed management, water quality management, fish seed handling, and pond preparation) are very much presented (averaged more than 14\%). Pond preparation is the category most presented in 34 titles (18.58\%). Meanwhile, the other three categories (harvest handling \& marketing, water supply, and fish pests \& disease control) presented less than $10 \%$. According to [20] and [21], the aquaculture extension materials must be complete, so that fish farmers can fully understand the issues being discussed.

Almost all text format extension materials are medium text (700 - 1,700 words) and shorter text (less than 700 words). Medium text extension materials were the most presented, 122 out of 183 titles $(66.67 \%)$. Meanwhile, short text extension materials (less than 700 words) reached almost $30 \%$. The ideal size of a text material is between $400-1,700$ words.

Most of the extension materials in text format are recommendations, 131 out of 183 titles $(71.58 \%)$. Problemsolving material are only 89 titles $(48.63 \%)$. This figure shows that several titles cover both categories at once. The MFCE website only presents a few problem-solving materials. According to [22], good extension materials help solve problems faced by fish farmers.

Pearson correlation analysis was used to see the correlation between variables/categories/indicators in text format extension materials. The relationship is strong if the Pearson correlation coefficient $(\mathrm{r})$ value is greater than 0.5 [11]. If the r-value is close to 1 , the relationship is very strong. The analysis results show that 37 variables/categories/indicators are strongly related, as shown in Table II.

TABLE II

COEFFICIENT OF PEARSON CORRELATION

VARIABLES/CATEGORIES/INDICATORS OF TEXT FORMAT MATERIALS

\begin{tabular}{|c|c|c|c|}
\hline No & Code A & Code B & $\mathbf{r}$ \\
\hline \multirow[t]{3}{*}{1} & Nodes $\backslash \backslash$ Extension & Nodes $\backslash \backslash$ Media & 0.959163 \\
\hline & Materials & Element & \\
\hline & Nature $\backslash$ Recommendation & SizelShort Text & \\
\hline \multirow[t]{3}{*}{2} & Nodes $\backslash \backslash$ Extension & Nodes $\backslash \backslash$ Media & 0.914027 \\
\hline & Materials & Element & \\
\hline & Nature \Recommendation & Size $\backslash$ Medium Text & \\
\hline \multirow[t]{3}{*}{3} & Nodes $\backslash \backslash$ Extension & Nodes $\backslash \backslash$ Media & 0.870521 \\
\hline & Materials & Element & \\
\hline & Nature\Problem-solving & SizelShort Text & \\
\hline \multirow[t]{3}{*}{4} & Nodes $\backslash \backslash$ Extension & Nodes $\backslash \backslash$ Extension & 0.853755 \\
\hline & Materials & Materials Nature $\backslash$ & \\
\hline & Nature \Recommendation & Problem-solving & \\
\hline \multirow[t]{3}{*}{5} & Nodes $\backslash \backslash$ Extension & Nodes $\backslash \backslash$ Element & 0.762803 \\
\hline & Materials & Media Sizel & \\
\hline & Nature \Recomendation & Medium Text & \\
\hline$\cdots$ & $\cdots$ & $\ldots$ & .. \\
\hline \multirow[t]{2}{*}{37} & Nodes $\backslash \mid$ Fish & Nodes $\backslash$ ¿Element & 0.511241 \\
\hline & Species\Tilapia Fish & $\begin{array}{l}\text { Media Size } \backslash \text { Long } \\
\text { Text }\end{array}$ & \\
\hline
\end{tabular}

The strongest relationship was between "recommendation" and "short text" extension materials $(\mathrm{r}=$ 0.959163). The relationship visualization illustrated in Fig. 3.

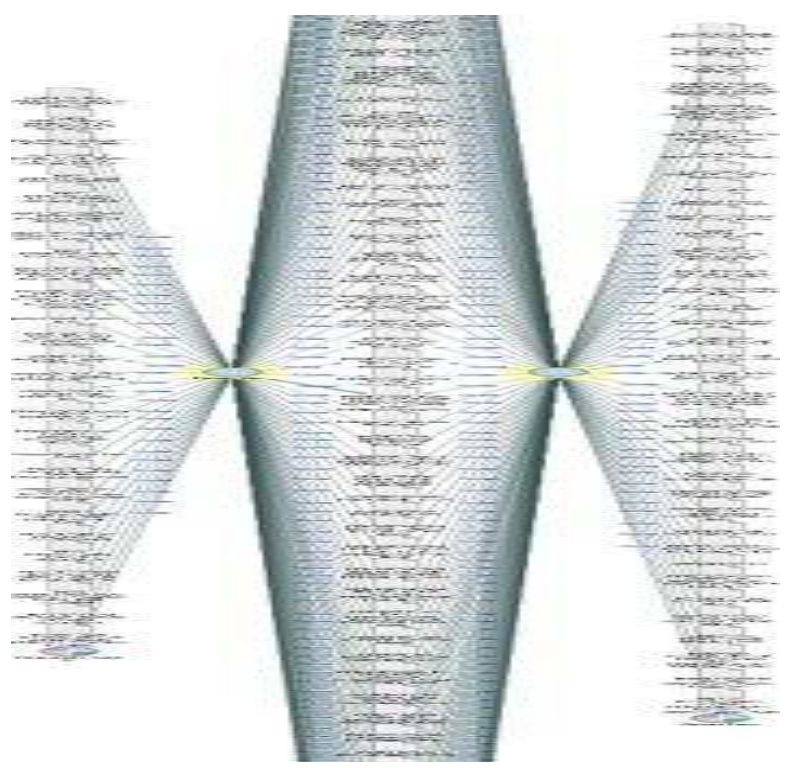

Fig. 3 Correlation visualization of "recommendation" and "short text" in text format extension materials 
It shows that extension materials of "recommendation" and "short text" are the most discussed variables/categories/ indicators compared to others.

\section{B. Graphic Format of Aquaculture Cyber Extension Materials}

The analysis results of the graphic format extension materials showed that the word size of "ikan" (fish) in the word cloud visualization, look is bigger than the other word size (except the conjunctions), as shown in Fig. 4.

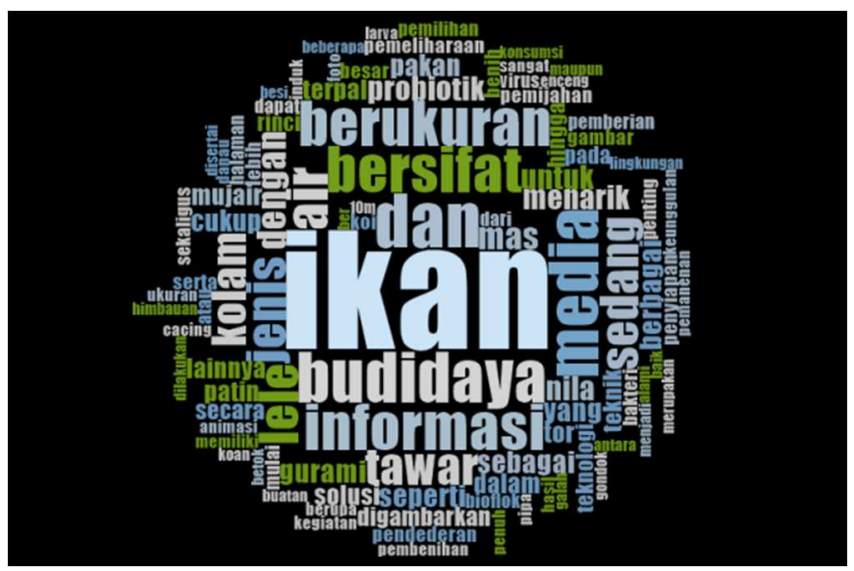

Fig. 4 The word cloud visualization for graphic format extension materials

This means that fish is the word that appears most often in the materials. The word of "ikan" (fish) occurs 83 times (6.37\% of the 100 most occurring words). The ten common words appear are fish, aquaculture, media, information, sized, water, species, catfish, fresh, and pond, as shown in Fig 5.

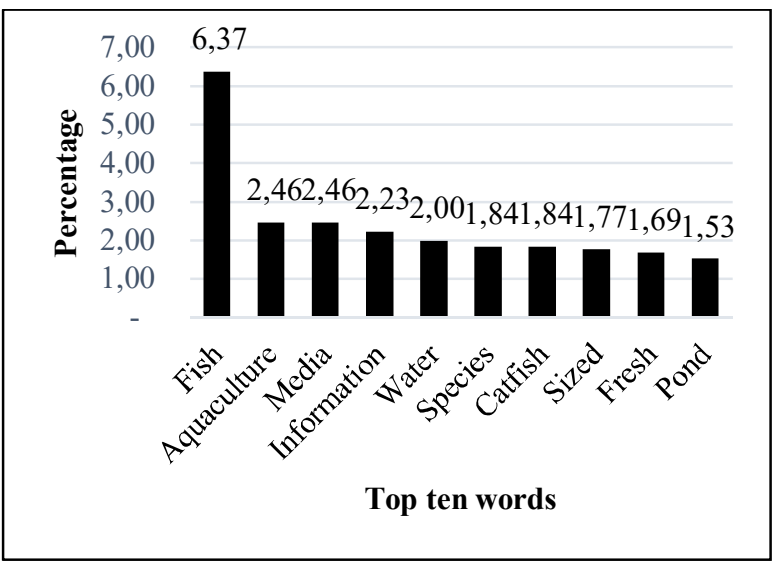

Fig. 5 Top ten words in the graphic format extension materials

The analysis results showed that the six freshwater fish species with high economic value were presented in graphic format extension materials on the MFCE website, more than 34 percent on average. Catfish is the fish species most served, 17 out of 29 titles $(58.52 \%)$, as shown in Table III. Although the presentation of "other fish" is more than catfish, 19 titles $(65.52 \%)$, but this category consists of six fish species, so the average percentage per fish species is small $(10 \%)$. The six fish species are eel (Anguilla marmorata), featherback (Chitala bornensis), koi (Cyprinus rubrofuscus), sultan fish (Leptobarbus hoeveni), climbing perch (Anabas testudineus), and kissing gourami (Helostoma themminckii).
TABLE III

VARIABLE ANALYSIS RESULTS OF GRAPHIC FORMAT AQUACULTURE EXTENSION MATERIALS

\begin{tabular}{|c|c|c|c|}
\hline Variables & Categories & $\begin{array}{l}\text { Number } \\
\text { of Titles }\end{array}$ & $\begin{array}{l}\text { Proporti- } \\
\text { ons of } 29 \\
\text { Titles (\%) }\end{array}$ \\
\hline \multirow{7}{*}{$\begin{array}{l}\text { Fish } \\
\text { Species }\end{array}$} & - Other fish & 19 & 65.52 \\
\hline & - Catfish & 17 & 58.52 \\
\hline & - Carp & 12 & 41.38 \\
\hline & - Nile Tilapia & 12 & 41.38 \\
\hline & - Giant Gourami & 11 & 37.93 \\
\hline & - Parrotfish & 10 & 34.48 \\
\hline & - Tilapia Fish & 10 & 34.48 \\
\hline \multirow{7}{*}{$\begin{array}{l}\text { Elements of } \\
\text { Aqua- } \\
\text { culture } \\
\text { Manage- } \\
\text { ment }\end{array}$} & - Pond Preparation & 8 & 27.59 \\
\hline & $\begin{array}{l}\text { - Fish Harvesting \& } \\
\text { Marketing Activities }\end{array}$ & 6 & 20.69 \\
\hline & - Fish Seed Handling & 6 & 20.69 \\
\hline & - Water Supply & 5 & 17.24 \\
\hline & - Feed Management & 5 & 17.24 \\
\hline & $\begin{array}{l}\text { Water Quality } \\
\text { Management }\end{array}$ & 5 & 17.24 \\
\hline & $\begin{array}{l}\text { - Fish Pests \& Disease } \\
\text { Control }\end{array}$ & 3 & 10.34 \\
\hline \multirow{3}{*}{$\begin{array}{l}\text { Media } \\
\text { Element } \\
\text { Size }\end{array}$} & $\begin{array}{l}\text { - Medium Size (380x285 } \\
\text { pixels) }\end{array}$ & 23 & 79.31 \\
\hline & $\begin{array}{l}\text { - Large Size (1240x903 } \\
\text { pixels) }\end{array}$ & 6 & 20.69 \\
\hline & $\begin{array}{l}\text { - Small Size }(380 \times 214 \\
\text { pixels })\end{array}$ & 0 & 0.00 \\
\hline \multirow{2}{*}{$\begin{array}{l}\text { Nature of } \\
\text { Extension } \\
\text { Materials }\end{array}$} & - Recommendation & 29 & 100.00 \\
\hline & - Problem-solving & 9 & 31.03 \\
\hline
\end{tabular}

The seven categories of aquaculture management were discussed in graphic format extension materials. The most discussed category was "pond preparation", found in eight of the 29 material titles $(27.59 \%)$. While the least is "fish pests \& diseases control", only in three titles $(10.34 \%)$. But, the other five categories were discussed quite a lot, between 5-6 material titles (average above 17\%). This finding is quite encouraging because the materials on aquaculture management are presented on the MFCE website. According to [23], complete aquaculture management information can help fish farmers improve business quality.

Almost $80 \%$ of the graphic format extension materials are presented in the medium size $(380 \times 285$ pixels) or two-thirds the width of the gadget screen. The rest are of the large size (1204 x 903 pixels) or as wide as the gadget screen.

The analysis results also show that all graphic format extension materials are in the form of recommendations, in all of the material titles (100\%). While the problem-solving material is only presented in nine titles $(31.03 \%)$. This means several material titles cover both categories at once. So, it can be concluded that the MFCE website does not provide sufficient graphic extension materials that are problemsolving.

Pearson correlation analysis was used to see the correlation between variables/categories/indicators in graphic format extension materials. The analysis results show that six variables/categories/indicators are strongly related (rvalue $>0.5$ ), as shown in Table IV. 
TABLE IV

COEFFICIENT OF PEARSON CORRELATION VARIABLES/CATEGORIES/INDICATORS OF GRAPHIC FORMAT MATERIALS

\begin{tabular}{|c|c|c|c|}
\hline No & Code A & Code B & $r$ \\
\hline \multirow[t]{3}{*}{1} & Nodes $\backslash \backslash$ Extension & Nodes $\backslash$ Element & \multirow[t]{3}{*}{0.981828} \\
\hline & Materials Nature $\backslash$ & Media Size $\backslash$ & \\
\hline & Recommendation & Medium Size & \\
\hline \multirow[t]{3}{*}{2} & Nodes $\backslash \backslash$ Extension & Nodes $\backslash$ Element & \multirow[t]{3}{*}{0.889355} \\
\hline & Materials Nature $\backslash$ & Media Size \Large & \\
\hline & Problem-solving & Size & \\
\hline \multirow[t]{3}{*}{3} & Nodes $\backslash \backslash$ Extension & Nodes $\backslash \backslash$ Element & \multirow[t]{3}{*}{0.790124} \\
\hline & Materials Nature $\backslash$ & Media Size $\backslash$ & \\
\hline & Problem-solving & Medium Size & \\
\hline \multirow[t]{3}{*}{4} & Nodes $\backslash \backslash$ Extension & Nodes $\backslash \backslash$ Element & \multirow[t]{3}{*}{0.745834} \\
\hline & Materials Nature $\backslash$ & Media Size $\backslash$ Large & \\
\hline & Recommendation & Size & \\
\hline \multirow[t]{3}{*}{5} & Nodes $\backslash \backslash$ Aquaculture & Nodes $\backslash \backslash$ Fish & \multirow[t]{3}{*}{0.541691} \\
\hline & Management $\backslash$ & Species $\backslash$ Other Fish & \\
\hline & Fish Seed Handling & & \\
\hline \multirow[t]{3}{*}{6} & Nodes $\backslash \backslash$ Aquaculture & Nodes $\backslash$ Fish & \multirow[t]{3}{*}{0.502602} \\
\hline & Management $\backslash$ Water & Species $\backslash$ Other Fish & \\
\hline & Quality Management & & \\
\hline
\end{tabular}

The strongest relationship was between "recommendation" and "medium size" extension materials (rvalue $=0.981828$, or close to 1$)$. The relationship visualization illustrated in Fig. 6.

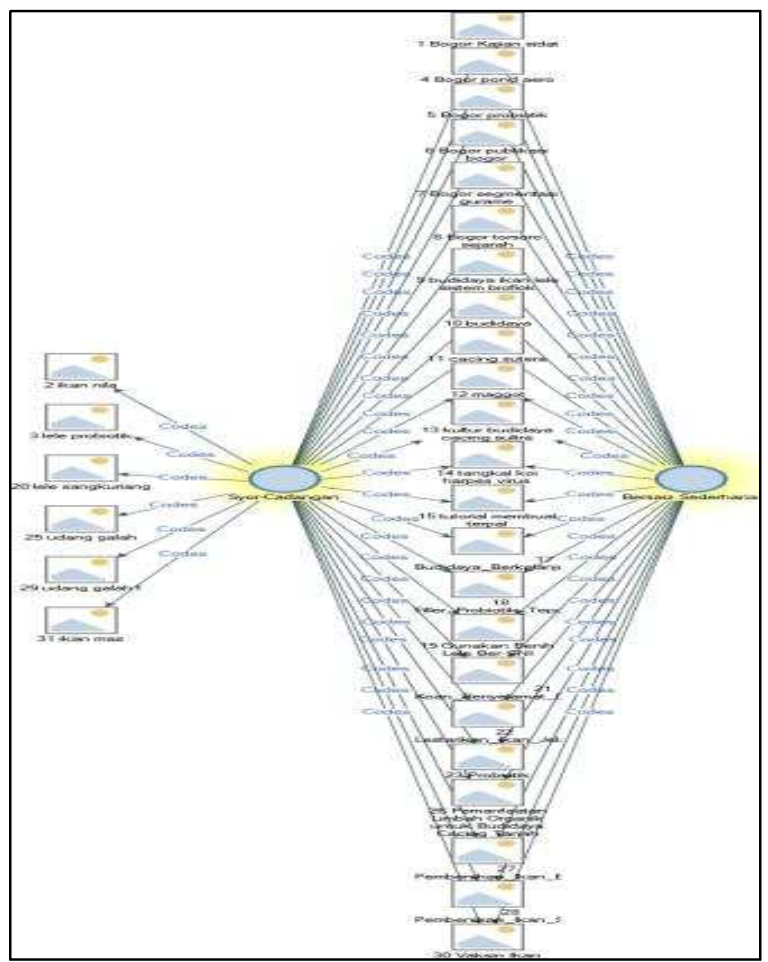

Fig. 6 Correlation visualization of "recommendation" and "medium size" in graphic format extension materials

It shows that extension materials of "recommendation" and "medium size" are the most discussed variables/categories/ indicators compared to others.

\section{Video Format of Aquaculture Cyber Extension Materials}

The analysis results of the video format extension materials showed that the "ikan" (fish) word size in the word cloud visualization look is bigger than the other word size, as shown in Fig. 7.

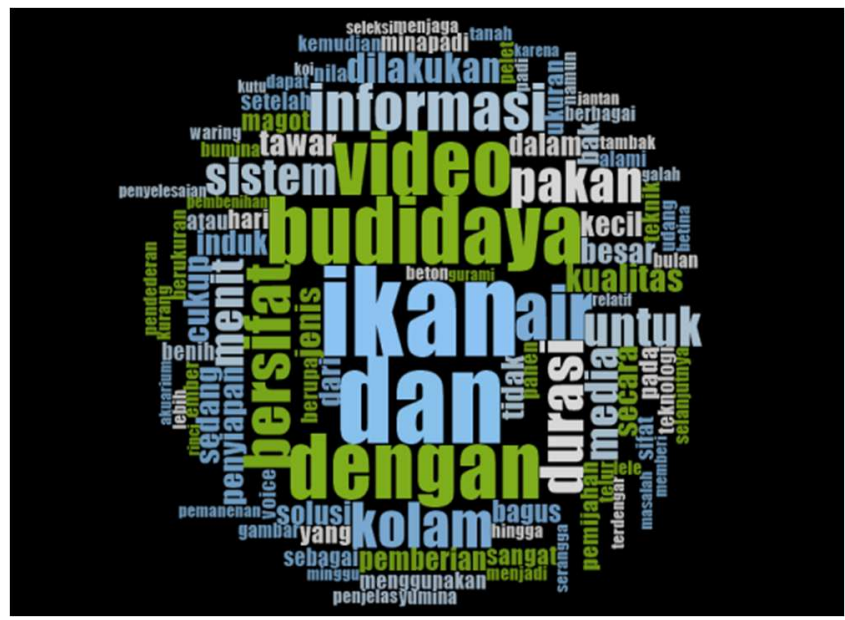

Fig. 7 The word cloud visualization for video format extension materials

This means that fish is the word that appears most often in the materials. The word of "ikan" (fish) occurs 88 times of the 100 most occurring words $(3.45 \%)$. The ten common words that appear are fish, aquaculture, water, information, pond, feed, system, quality, species, and fresh, as shown in Fig. 8.

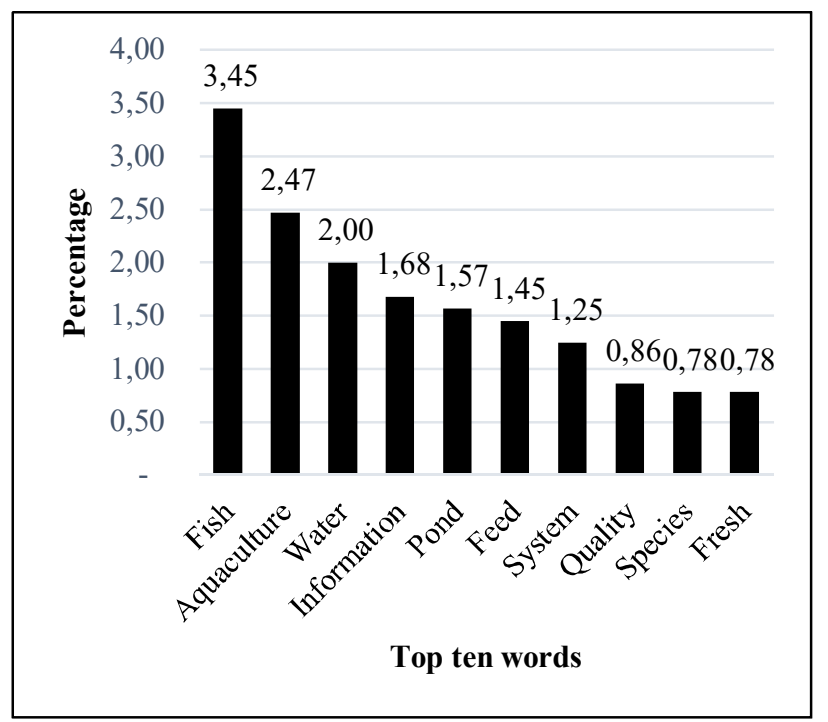

Fig. 8 Top ten words in the video format extension materials

The analysis results show that the video format extension materials discuss all the six fish species with high economic value. The material title number that discusses, it is almost the same, an average of more than $34 \%$ for each fish species.

Nile tilapia is the fish species most served, 31 out of 53 titles (58.49\%), as shown in Table V. Although the presentation of "other fish" category is more than nile tilapia, 38 titles $(71.70 \%)$, but this category consists of ten fish species, so the average percentage per fish species is small (7.1\%). The ten fish species are wallago attu (Wallago leeri), hoven's carp (Leptobarbus hoevenii), climbing perch (Anabas testudineus), kissing gourami (Helostoma themminckii), green catfish (Hemibagrus nemurus), swamp eel (Monopterus albus), eel (Anguilla marmorata), featherback (Chitala bornensis), barb (Barbonymus gonionotus), and koi (Cyprinus rubrofuscus). 
TABLE V

VARIABLE ANALYSIS RESULTS OF VIDEO FORMAT AQUACULTURE EXTENSION MATERIALS

\begin{tabular}{|c|c|c|c|}
\hline Variables & Categories & $\begin{array}{l}\text { Number } \\
\text { of Titles }\end{array}$ & $\begin{array}{l}\text { Proportions } \\
\text { of } 53 \text { Titles } \\
(\%) \\
\end{array}$ \\
\hline \multirow{7}{*}{$\begin{array}{l}\text { Fish } \\
\text { Species }\end{array}$} & - Other fish & 38 & 71.70 \\
\hline & - Nile Tilapia & 31 & 58.49 \\
\hline & - Giant Gourami & 30 & 56.60 \\
\hline & - Catfish & 29 & 54.72 \\
\hline & - Parrotfish & 27 & 50.94 \\
\hline & - Tilapia Fish & 25 & 47.17 \\
\hline & - Carp & 24 & 45.28 \\
\hline \multirow{7}{*}{$\begin{array}{l}\text { Element } \\
\text { of Aquacul- } \\
\text { ture Manage- } \\
\text { ment }\end{array}$} & - Feed Management & 18 & 33.96 \\
\hline & - Pond Preparation & 18 & 33.96 \\
\hline & $\begin{array}{l}\text { - Fish Seed } \\
\text { Handling }\end{array}$ & 16 & 30.19 \\
\hline & $\begin{array}{l}\text { - Fish Harvesting \& } \\
\text { Marketing } \\
\text { Activities }\end{array}$ & 13 & 24.53 \\
\hline & $\begin{array}{l}\text { - Water Quality } \\
\text { Management }\end{array}$ & 12 & 22.64 \\
\hline & - Water Supply & 6 & 11.32 \\
\hline & $\begin{array}{l}\text { - Fish Pests \& } \\
\text { Disease Control }\end{array}$ & 5 & 9.43 \\
\hline \multirow[t]{3}{*}{$\begin{array}{l}\text { Media } \\
\text { Element Size }\end{array}$} & $\begin{array}{l}\text { - Long Duration (>9 } \\
\text { minutes) }\end{array}$ & 19 & 35.85 \\
\hline & $\begin{array}{l}\text { - Medium Duration } \\
(4.5-9 \text { minutes })\end{array}$ & 18 & 33.96 \\
\hline & $\begin{array}{l}\text { - Short Duration } \\
(<4.5 \text { minutes })\end{array}$ & 16 & 30.19 \\
\hline \multirow{2}{*}{$\begin{array}{l}\text { Nature of } \\
\text { Extension } \\
\text { Materials }\end{array}$} & - Recommendation & 45 & 84.91 \\
\hline & - Problem-solving & 17 & 32.08 \\
\hline
\end{tabular}

All aquaculture management categories are discussed in video format extension materials. The most covered are fish feed management, pond preparation, and fish seed handling, an average of more than 15 titles $(30 \%)$. While the least is "control of fish pests \& diseases", only five titles $(9.43 \%)$.

This finding shows that the video material on aquaculture management on the MFCE website is not discussed evenly. There are two elements of management with a small portion of the discussion, water supply, and fish pests \& disease control. All elements should be discussed in equal portions because according to [24], these elements are interrelated with each other. The ideal length of video extension material is $4.5-9$ minutes. The analysis results show that there are only 18 out of 53 video titles (33.96\%) with a duration of 4.5 - 9 minutes (medium duration). Thus, most of the length of the extension videos presented on the MFCE website is not ideal. According to [25], the extension video duration that is too long will look boring, thus disrupting the present of the message. Meanwhile, if the duration is too short, it cannot convey the complete message [26]. The analysis results show that most of the video format extension materials are only recommendations, almost $85 \%$ of all material titles. This amount is not ideal because fish farmers need problemsolving materials. Pearson correlation analysis was used to see the correlation between variables/categories/indicators in graphic format extension materials. The analysis results show that 10 variables/categories/indicators are strongly related ( $\mathrm{r}-$ value $>0.5$ ), as shown in Table VI.
TABLE VI

COEFFICIENT OF PEARSON CORRELATION VARIABLES/CATEGORIES/INDICATORS OF VIDEO FORMAT MATERIALS

\begin{tabular}{|c|c|c|c|}
\hline No & Code A & Code B & $r$ \\
\hline \multirow[t]{3}{*}{1} & Nodes $\backslash$ Extension & Nodes \\
Element Media & 0.901 \\
\hline & Materials Nature $\backslash$ & Size $\backslash$ Medium Duration & 481 \\
\hline & Problem-solving & & \\
\hline \multirow[t]{3}{*}{2} & Nodes $\backslash \backslash$ Extension & Nodes $\backslash \backslash$ Element Media & 0.881 \\
\hline & Materials Nature $\backslash$ & Size $\backslash$ Long Duration & 531 \\
\hline & Recommendation & & \\
\hline \multirow[t]{3}{*}{3} & Nodes $\backslash \backslash$ Extension & Nodes $\backslash \backslash$ Element Media & 0.877 \\
\hline & Materials Nature $\backslash$ & Size $\backslash$ Medium Duration & 053 \\
\hline & Recommendation & & \\
\hline \multirow[t]{3}{*}{4} & Nodes $\backslash \backslash$ Extension & Nodes $\backslash \backslash$ Element Media & 0.875 \\
\hline & Materials Nature $\backslash$ & Size $\backslash$ Short Duration & 303 \\
\hline & Recommendation & & \\
\hline \multirow[t]{3}{*}{5} & Nodes $\backslash \backslash$ Extension & Nodes $\backslash \backslash$ Extension & 0.847 \\
\hline & Materials Nature $\backslash$ & Materials Nature \Problem- & 784 \\
\hline & Recommendation & solving & \\
\hline \multirow[t]{3}{*}{6} & Nodes $\backslash \backslash$ Extension & Nodes $\backslash \backslash$ Elemen Media & 0.808 \\
\hline & Materials Nature $\backslash$ & Size \Long Duration & 967 \\
\hline & Problem-solving & & \\
\hline \multirow[t]{3}{*}{7} & Nodes $\backslash \backslash$ Extension & Nodes $\backslash \backslash$ Element Media & 0.652 \\
\hline & Materials Nature $\backslash$ & SizelShort Duration & 885 \\
\hline & Problem-solving & & \\
\hline \multirow[t]{2}{*}{8} & Nodes $\backslash \backslash$ Element Media & Nodes $\backslash$ Element Media & 0.633 \\
\hline & Size $\backslash$ Short Duration & Size $\backslash$ Long Duration & 222 \\
\hline \multirow[t]{3}{*}{9} & Nodes $\backslash \backslash$ Aquaculture & Nodes $\backslash \backslash$ Fish & 0.525 \\
\hline & Management $\backslash$ Fish & Species $\backslash$ Catfish & 601 \\
\hline & Feed Management & & \\
\hline \multirow[t]{2}{*}{10} & Nodes $\backslash \backslash$ Aquaculture & Nodes $\backslash \backslash$ Fish & 0.506 \\
\hline & $\begin{array}{l}\text { Management } \backslash \text { Pond } \\
\text { Preparation }\end{array}$ & Species $\backslash$ Catfish & 331 \\
\hline
\end{tabular}

The strongest relationship was between "problem-solving" and "medium duration" extension materials (r-value = 0.901481 , or close to 1$)$. The relationship visualization illustrated in Fig. 9.

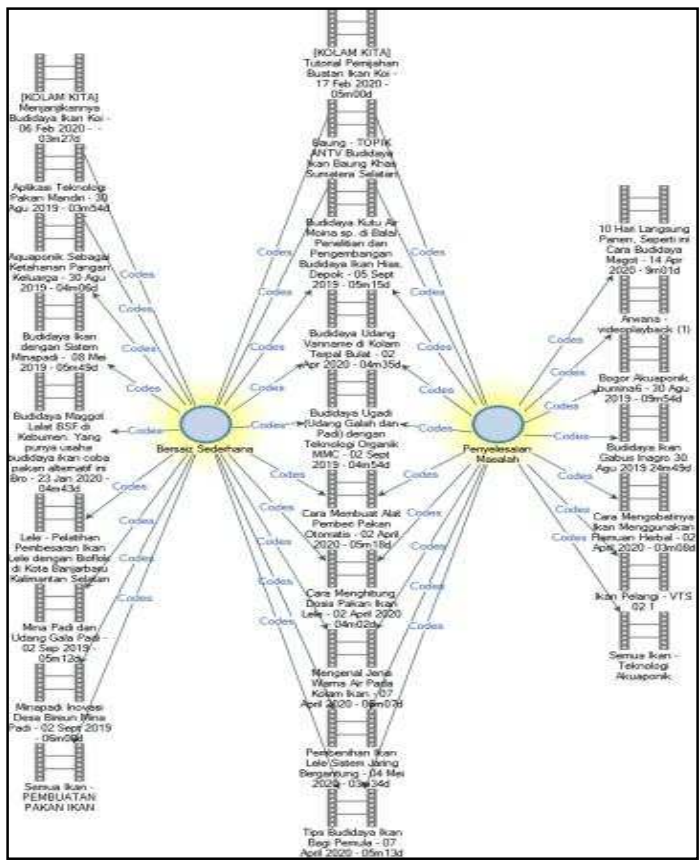

Fig. 9 Correlation visualization of "recommendation" and "medium size" in video format extension materials

It shows that extension material of "problem-solving" and "medium duration" is the most discussed variables/categories/indicators compared to others. Whereas, according to [27], problem-solving counselling materials are 
needed to intervene in the minds of the public to improve the quality of their business.

\section{CONCLUSION}

This study concludes that aquaculture cyber extension materials on the MFCE website are only presented in text, graphic, and video media formats. There are no other formats like animation and interactivity yet. The three media formats present all the six fish species of high economic value recommended by the Indonesian government. The video media presents more information about the nile tilapia species (58.49\% of all titles of extension materials). While graphic and text media presented more materials on catfish, $58.52 \%$ and $55.10 \%$ each. The three media also present all the seven aquaculture management elements. Graphic and text media presents more content on management of pond preparation, $27.59 \%$ and $18.58 \%$ of all extension materials titles respectively. While the video media presents more information on fish feed management (33.96\%). The text and graphics extension media size are ideal with most of the text material containing $700-1,700$ words $(66.67 \%)$ and graphic measuring $380 \times 285$ pixels $(79.31 \%)$. The video duration that is ideal (4.5 - 9 minutes), very few, only $33.96 \%$. Most of the extension material is for recommendations only and not problem-solving. The graphic media material are all (100\%) recommendations, video media $(84.91 \%)$, and text media $(71.58 \%)$.

The MFCE website only has three media elements, includes text, graphics, and video. Meanwhile, the other three are audio, animation, and interactivity, were not present. In fact, those three media elements are potentially good for cyber extension programs. It is unknown why the website does not serve it. This is a challenge for future researchers to conduct more studies.

\section{ACKNOWLEDGMENT}

The authors are greatful to Faculty of Fisheries and Marine University of Riau, and Universiti Selangor.

\section{REFERENCES}

[1] N. Tran et al., "Indonesian aquaculture futures: An analysis of fish supply and demand in Indonesia to 2030 and role of aquaculture using the AsiaFish model," Mar. Policy, vol. 79, no. May, pp. 25-32, 2017, doi: 10.1016/j.marpol.2017.02.002.

[2] M. Rahmizal, "Analysis of Indonesia Marine Fisheries with Economic Growth, Population and Effort Effectiveness,” Eur. J. Eng. Form. Sci., vol. 1, no. 1, p. 17, 2017, doi: 10.26417/ejef.v1i1.p17-22.

[3] FAO, "Aquaculture," Website FAO, 2019. http://www.fao.org/3/x6941e/x6941e04.htm (accessed Jul. 20, 2019).

[4] M. Fauzi, D. Dahelmi, I. J. Zakaria, and U. M. Tang, "Biological aspects of lelan fish, Diplocheilichthys pleurotaenia (Cyprinidae) from the upstream and downstream of the Kampar River, Riau Province, Indonesia," AACL Bioflux, vol. 9, no. 2, pp. 305-315, 2016.

[5] R. Hendri, H. S. A. Nawi, and A. Ibrahim, "The impact of aquaculture cyber extension on fish farmers' attitudes and behavior in Riau, Indonesia," AACL Bioflux, vol. 14, no. 4, pp. 1965-1973, 2021

[6] A. P. A. Samad, R. Humaraini, N. R. Purnama, and E. Ayuzar, "Marine fisheries and aquaculture production of Indonesia: Recent status of GDP growth," J. Mar. Sci. Res. Oceanogr., vol. 3, no. 4, pp. 135-139, 2020, doi: 10.33140/jmsro.03.04.04.

[7] Budijono, U. M. Tang, R. M. Putra, and Nofrizal, "Dynamic of water fertility in Koto Panjang reservoir, Riau Province, Indonesia," $A A C L$ Bioflux, vol. 14, no. 2, pp. 965-975, 2021.

[8] Z. Ahmed, M. A. Sarker, M. Z. Rahman, B. Lei, and M. Z. N. Mukta, "Fisheries extension in Bangladesh and local extension agent for fisheries: A micro level assessment of farmers' Attitude," Int. J. Fish. Aquat. Stud., vol. 6, no. 4, pp. 92-103, 2018, [Online]. Available: www.fisheriesjournal.com.

[9] C. C. Nguemo, M. Tita, and M. A. Abdel-Wahhab, "Pesticide knowledge and safety practices in farm workers from Tubah SubDivision, North West Region, Cameroon," Int. J. Halal Res., vol. 1, no. 1, pp. 39-47, 2019, doi: 10.18517/ijhr.1.1.39-47.2019.

[10] Pusat Penyuluhan Kelautan dan Perikanan KKP-RI, "Information System for Dissemination of Marine and Fisheries Extension Materials," 2018. http://mfcepusluh.bpsdmkp.kkp.go.id/ (accessed Dec. 09, 2018)

[11] J. W. Creswell, Research Design: Qualitative, Quantitative and Mixed Method Aproaches, $3^{\text {rd }}$ ed. Thousand Oaks, California: Sage Publications, 2009.

[12] Eriyanto, Content Analysis: An Introduction to Methodology for Research in Communication and Other Social Sciences, $3^{\text {rd }}$ ed. Jakarta: Prenanamedia Group, 2015.

[13] B. A. Muis, K. Murtilaksono, I. N. S. Jaya, and O. Haridjaja, "Analysis of water demands for freshwater aquaculture ponds in Krueng Aceh watershed, Aceh Province, Indonesia," AACL Bioflux, vol. 10, no. 5, pp. 1119-1126, 2017.

[14] N. Serdiati et al., "Andinoacara rivulatus (Perciformes: Cichlidae), an introduced exotic fish in the upstream of brantas river, indonesia," AACL Bioflux, vol. 13, no. 1, pp. 137-141, 2020.

[15] R. K. Abdel-Wahed, I. M. Shaker, M. A. Elnady, and M. A. M. Soliman, "Impact of fish-farming management on water quality, plankton abundance and growth performance of fish in earthen ponds," Egypt. J. Aquat. Biol. Fish., vol. 22, no. 1, pp. 49-63, 2018, doi: 10.21608/ejabf.2018.7705.

[16] Ihsan et al., "Aquaculture management of blue swimming crab (Portunus pelagicus) using integrated submerged net cage in pangkep regency waters, south Sulawesi, Indonesia," AACL Bioflux, vol. 13, no. 6, pp. 3279-3286, 2020.

[17] R. Hendri and E. Yulinda, Fisheries Development Communication Media, $1^{\text {st }}$ ed. Pekanbaru: Universitas Riau Press, 2019.

[18] S. Diliarosta and A. Hardinata, "The effects of agricultural extension for improvement environmental behavior by vegetable farmers in Padang city," J. Phys. Conf. Ser., vol. 1185, no. 012144, pp. 1-5, 2019, doi: 10.1088/1742-6596/1185/1/012144.

[19] K. G. Gebrehiwot, "The impact of agricultural extension on farmers' technical efficiencies in Ethiopia: A stochastic production frontier approach," South African J. Econ. Manag. Sci., vol. 20, no. 1, pp. 18, 2017, doi: 10.4102/sajems.v20i1.1349.

[20] F. Jane, M. A. Opiyo, K. Obiero, and J. Munguti, “Aquaculture extension service in Kenya: Farmers and extension officers perspectives," J. Agric. Ext. Rural Dev., vol. 13, no. 1, pp. 14-22, 2021, doi: 10.5897/JAERD2020.1203.

[21] C. C. Nguemo, M. Tita, and M. A. Abdel-Wahhab, "Preliminary screening of pesticides used by farmers in North West Cameroon," Int. J. Halal Res., vol. 1, no. 1, pp. 48-55, 2019, doi: 10.18517/ijhr.1.1.48-55.2019.

[22] E. Sugiharto, E. Purnamasari, A. Jati, and S. Rini, "The Effectivity of Fisheries Extension Method against the Attitude of Pokdakan Members 'Senyum Terpadu' in Makroman Municipal, Samarinda City Indonesia," in Proceedings of the National Wetland Environment Seminar, 2019, vol. 4, no. April, pp. 471-476.

[23] D. A. Taskov, T. C. Telfer, D. A. Bengtson, M. A. Rice, D. C. Little, and F. J. Murray, "Managing aquaculture in multi-use freshwater bodies: The case of Jatiluhur reservoir," Environ. Res. Lett., vol. 16, no. 4, pp. 1-13, 2021, doi: 10.1088/1748-9326/abe009.

[24] P. Wang, J. Ji, and Y. Zhang, "Aquaculture extension system in China: Development, challenges, and prospects," Aquac. Reports, vol. 17, no. November 2019, p. 100339, 2020, doi: 10.1016/j.aqrep.2020.100339.

[25] B. Van Campenhout, S. Vandevelde, W. Walukano, and P. Van Asten, "Agricultural extension messages using video on portable devices increased knowledge about seed selection, storage and handling among smallholder potato farmers in Southwestern Uganda," PLoS One, vol. 12, no. 1, pp. 1-20, 2017, doi: 10.1371/journal.pone.0169557.

[26] K. Slemmons et al., "The impact of video length on learning in a middle-level flipped science setting: Implications for diversity inclusion," J. Sci. Educ. Technol., vol. 27, no. 2, pp. 1-11, 2018, doi: 10.1007/s10956-018-9736-2.

[27] A. S. A. El-Nahhas, "The effectiveness of a rational, emotional, behavioral program in modifying the irrational thoughts related to the pressures of life for forced retirees," Int. J. Halal Res., vol. 2, no. 2, pp. 106-125, 2020, doi: 10.18517/ijhr.2.2.106-125.2020. 